adumbrated in "The Rise of Scientific Philosophy", published in 1951. The thesis maintained is that while determinism excludes complete freedom of the will, probabilistic causality does not, and a "noncognitive theory of ethics" is advanced of which the essence is "the recognition of the non-logical relation between knowledge and action". This is consistent with the author's general philosophy of science, of which "The Rise of Scientific Philosophy" gives an admirable account. Owing to the much more speculative nature of the subject, however, it is scarcely likely to carry the same conviction as the epistemological discussions which are more directly related to the actual content of modern physical theory.

Herbert Dingle

\section{SOCIOLOGY: THE NEW HOPE}

The Sociological Imagination

By C. Wright Mills. Pp. vii +234 . (London and New York: Oxford University Press, 1959.) $36 s$. net.

THIS book has, in effect, three themes: (1) a sociological account of the present state of the social sciences themselves, and particularly of the state of sociology in the United States; (2) recommendations concerning what the social sciences should be like, and finally, (3) reflexions on our times. The three themes are, of course, closely interwoven, for the account of current sociology is largely a condemnation which calls for a specification of a better way, while the diagnosis of how the ills came about requires a discussion of the wider social factors responsible for them.

At the root of sociology and the social sciences lies a great hope and a promise - of a kind of collective self-knowledge. If there is one thing which ought to be obvious (though there are still people to whom it is not) it is that society constrains us, that our lives, thoughts and aims are, at the very least, conditioned by a social framework we never made or chose, and in a way we often do not understand. Sometimes, and for those fortunate enough to be in a congenial environment, this is no source of sorrow : but when the insight is combined with a partial rejection or failure of current values and institutions, it leads to a hope of control through knowledge. This hope, as Prof. Mills reminds us, was at the origin of sociology, and it still powerfully animates him-if not all his colleagues.

If there is one country where this hope might be thought to have better expectations of fulfilment than elsewhere, it is the United States, where sociology is a recognized and extensive profession, where it is neither muzzled (as it is behind the Iron Curtain), nor ignored as the dubious fad of a marginal minority. In fact, the picture in the United States is not at all rosy, despite the number of sociologists and the recognition they receive. Prof. Mills provides an explanation, and he does it brilliantly.

A good deal of the output of the flourishing American sociological profession consists, using Mills's terms, of "Grand Theory" or of "Abstracted Empiricism". "Grand Theory", not to put too fine a point on it, is simply pretentious verbiage of a kind which has to be read to be believed. Prof. Mills charitably says that it does contain some ideas, and heroically extracts them for us. The respectable mice rescued. from under the mountains of rubbish are insightsvalid so far as they go and well suited for any systematic treatment of societies-such as that social life consists of the interaction of individuals with reason. ably stable reciprocal expectations, with shared values which had been inculcated by a common background, and so forth . . . (but not for very long, for this is nearly all there is in it).

"Abstracted Empiricism" consists of the proliferation of ritualized, standardized surveys, usually by means of questionnaires, in which the collection of dubiously valuable or even reliable data is guided by little thought or concern with genuine questions. The blindness of such "Abstracted Empiricism" complements the emptiness of "Grand Theory".

Prof. Mills gives us a convincing account of how these fashions came to be dominant. Their roots are various : the emulation of a false image of natural science, an image which was mistaken anyway, and which in any case, even if it were valid, could not be easily re-applied to social matters; the shift of the practical impulse from, roughly speaking, helping the poor to helping sales promotion and the manipulation of personnel; the safe political innocuousness of the new practices; the (probably inevitable) bureaucratic ethos inherent in the administration of foundations, expensivo and large-scale research, etc. (Natural scientists are fortunate in that the traditions of their subject were well established before our present era. One shudders to think what might have happened had the foundations existed in the early days of the Royal Society.)

Prof. Mills attempts to do more than describe and analyse the current ills, he also hopes to remedy them. His recommendations to sociologists are sound and perceptive. So are his reflexions on our times and the part that thought and valuation can play in the modern world. I only fear that he may implicitly - -in trying to stem the tide-be too optimistic, that the general social factors on the other side are too strong. I hope $X$ am wrong.

But this is not a book which will stand or fall by either the soundness or the success of its positive recommendations. It is already fully justified by the admirable account offered of an important if unattractive phenomenon, and one which is playing a very significant part in American life. This was, so to speak, a necessary book. Somebody had to write it, and we can all be thoroughly grateful that the somebody was Prof. C. Wright Mills. E. Gellner

\section{DAIRYING IN GREAT BRITAIN}

\section{The United Kingdom Dairy Industry}

Edited by Prof. E. L. Crossley. (Prepared under the auspices of the XV International Dairy Congress on behalf of the United Kingdom Dairy Association.) Pp. viii $+142+16$ plates. (London: United Kingdom Dairy Association, 1959.)

$T$ HIS book was written to mark the fifteenth International Dairy Congress held in London during the summer of 1959 ; it provides a valuable picture of the state of the dairy industry in the late fifties. Prof. E. L. Crossley, helped by a list of distinguished contributors, has distilled 142 remarkably uncluttered pages of useful information. $\mathrm{He}$ begins by setting dairying in relation to other branches of agriculture and reminds us that milk and dairy 